INTERNATIONAL JOURNAL OF MULTIDISCIPLINARY RESEARCH AND ANALYSis

ISSN(print): 2643-9840, ISSN(online): 2643-9875

Volume 04 Issue 02 February 2021

DOI: 10.47191/ijmra/v4-i2-09, Impact Factor: 6.072

Page No.- 155-167

\title{
Influence the Quality of Accounting Information Systems and the Effectiveness of Internal Control on Public Financial Reporting Quality; an Empirical Sturdy
}

\author{
Mayadunnege Senaka Anuruddha ${ }^{1}$, Prof. Prathiba Mahanamahewa ${ }^{2}$ \\ ${ }^{1}$ Senior Consultant, Sri Lanka Institute of Development Administration \\ ${ }^{2}$ Dean, Faculty of Law, University of Technology, Jamaica
}

\begin{abstract}
There is a growing concern over the public financial management practices including financial reporting of governments. People's concern over more productive public resource utilization has flourished. Not only that, transparency, accountability, and openness of public money utilizations have become more common. Financial reporting is a key leading instrument that is able to prove both ideas. The requirement stimulates governments to concern about the quality of financial reporting in the public sector. The government of Sri Lanka has already taken several steps to strengthen their public financial reporting while there are still being criticisms by critical interest parties. The situation creates a drought over the effectiveness and the direction of the initiatives. Based on the public financial reporting environment in Sri Lanka, the research investigates the determining factors of Public Financial Reporting Quality (PFRQ). Scholars acknowledge the influence of the Accounting Information System (AIS) and Internal Control (IC) to determine the PFRQ in different organizational environments. A questionnaire survey seeking opinions on these two areas was distributed to a sample of Accountants working in the central government ministries and departments in Sri Lanka. The results reveal the strong contribution of AIS and IC to enhance the PFRQ. The results further acknowledge the findings of previous scholars over the positive influence of AIS and IC to determine the FRQ. These findings contribute to the literature by analyzing the determinants of financial reporting quality in the public sector. Finally, it is recommending to the government of Sri Lanka to take steps to strengthen their public financial reporting in a correct and more influential direction.
\end{abstract}

KEYWORDS: Public Financial Reporting Quality (PFRQ), Accounting Information System (AIS), Internal Control (IC),

\section{INTRODUCTION}

The public sector financial reporting has a strong contribution to the accountability, transparency, and good governance of public finance as the most influential and interesting phenomenon for the public. The main reason why the quality of financial information is needed in governmental accounting is to assist the performance monitoring, to entrust governments with the management of assets and liabilities that have been accumulated over decades, and to have confidence in politicians to be willing to take an interest in voting. The General purpose of financial reporting in the government sector is fulfilling the peoples' information requirements regarding government financial position and performances in a given period. People are expecting to know the government's internal and external liabilities, outstanding payments, assets including what government earns within the given period and spends for. Peoples' expectations not limited to government financial position, today citizens expecting more than traditional information-wise program cost, unit cost, value for money, and some more important operational and performance-related financial information.

Financial reporting is key to performance analysis of any kind of organization including public sector organizations. It is major to measure economic activities. Financial decisions lead government entities at all the time that leads by financial reporting. Not only that, it is a mirror to see the financial position of any organization at a given time. Economic policymakers, regulating bodies, and investors are always keen on the financial reporting of an entity. Public sector financial reporting has a macro effect on the economy. It is expecting to maintain timeliness, reliability, completeness, in the financial reporting to cater to prudent, effective, and efficient financial decisions by various interested parties. Today, there is a widespread concern over financial information 


\section{Influence the Quality of Accounting Information Systems and the Effectiveness of Internal Control on Public Financial Reporting Quality; an Empirical Sturdy}

quality. Public financial reporting quality becomes an international level headline in related field scholar discussions. The financial reporting quality improvements debate highlights the requirement of high attention over the subject specialists, standard setters, regulators, professionals, and other interested parties and scholars. Mainly two factors influence the quality of financial reporting; Accounting Information System and Internal Controls.

There are many quarries over the public financial reporting system in Sri Lanka. Mainly, law makers, officials, and the general public question the ability of fulfilling essential information requirements by the system. The traditional financial reporting system which is based on regulations, guidelines and cash-based accounting has been found inadequate and some of the inherent weaknesses such as failure to recognize true costs, inability to recognize assets, and liabilities. Cash accounting can too easily neglect asset management, accumulating arrears, future liabilities (e.g., pensions), and contingent liabilities (e.g., guarantees). In the context of the Sri Lankan public sector, efforts are being in progress to transform its cash-based accounting to accrual accounting for nearly a decade. In the meantime, legislative bodies such as the Auditor General and Committee on Public Accounts has pointed out several major lapses in the Public Financial Management System of Sri Lanka. Some of those are; nonexistence of Fixed Asset Registers and Losses \& Damages Registers (CPA, 2013), unable to provide Revenue Accounts for years (CPA, 2013), lack of full disclosure of government liabilities (CPA, 2013) the terms and conditions of borrowing and the proxy borrowing of state banks to finance government expenditure (TISL, 2014). In this context, the research aims to revile and explain the determinants of Public Financial Reporting Quality in Sri Lanka to make recommendations for improvements.

\section{a. Significance of the Study}

The significance of this study lies in the fact that the consequence subsidizes to build the government confidence or otherwise in the action taken to do obligatory alterations and encouraging the public financial reporting to put their full weight on the implementation and adoption of required changes to improve Public Financial Reporting Quality in Sri Lanka. The study is also significant in the sense that the regulators to identify the factors and determinants of each factor affecting to determine Public Financial Reporting Quality. The Study further describes the level of effectiveness of each factor and its attributes affecting the Public Financial Reporting Quality in Sri Lanka. Any difficulties recognized would be taken sufficient care of before the enactment of the system. Further to that, the study is significant in the sense that it would help to build up literature on the assessment of the Quality of Public Financial Reporting and the identification of factors affecting to determine the same in Sri Lanka to achieve the desired financial reporting objectives of accountability, transparency, and improvement of quality on financial information.

\section{b. Problem Statement}

There is a growing concern creating by this situation on public financial reporting quality which safeguarded the public requirement of satisfactory financial information. Quality financial reports provide financial information which can inculcate present and future economic decisions in a trustworthy manner (Ramdany, 2015) that leads the mind of providing full disclosure on a timely basis of all material facts relating to government financial position and performance (CICA, 2013; Onyinyechi, et al. 2016). However, As USAID (2015) described, the Public Financial Management in Sri Lanka is fragmented and unable to ensure adequate and efficient use of public resources. The Public Financial Management administration which includes applications of processes and procedures is rather obsolete, promoting a lack of operational consistency in line ministries and agencies. There were constant criticisms by countries main legislative body; Committee on Public Accounts, over the weaknesses of financial reporting. There were series of efforts taken by the government and international donner agencies to improve the system though the criticisms remain. Considering the facts, the research has developed to test the applicability of theoretically and empirically tested influence of quality of AIS and the effectives of ICs in different grounds, in the public financial reporting environment in Sri Lanka. The facts developed its research statement here as "Whether there is a statistically positive significant influence over the PFRQ by the quality of AIS and the effectiveness of IC in Sri Lanka".

\section{c. Research Objectives}

Building upon the problem statement of the research, the overall research objective was to understand the influence of quality of AIS and the effectiveness of IC to determine the PFRQ particularly in the central government in Sri Lanka. To achieve this, the research derived its specific objectives as;

1. To examine the Public Financial Reporting Quality of the Central Government Ministries and Department in Sri Lanka.

2. To investigate the AIS quality of the Central Government Ministries and Department in Sri Lanka.

3. To identify the level of effectiveness of IC of the Central Government Ministries and Department in Sri Lanka.

4. To examine the level of influence of AIS quality in the Central Government Ministries and Department in Sri Lanka to determine the PFRQ. 


\section{Influence the Quality of Accounting Information Systems and the Effectiveness of Internal Control on Public Financial Reporting Quality; an Empirical Sturdy}

5. To measure the efficiency of IC in the Central Government Ministries and Department in Sri Lanka to determine the PFRQ.

\section{d. Research questions}

Having an outline, the research statement, the research questions address in this study includes,

1. What is the level of the quality of AIS in the Central Government Ministries and Departments in Sri Lanka?

2. What is the level of the effectiveness of IC in the Central Government Ministries and Departments in Sri Lanka?

3. What is the level of the PFRQ in the Central Government Ministries and Departments in Sri Lanka?

4. How does the quality of AIS in the Central Government Ministries and Departments in Sri Lanka contributing to the PFRQ?

5. How does the effectiveness of IC in the Central Government Ministries and Departments in Sri Lanka contributing to the PFRQ?

\section{e. Scope of the Research}

The scope of this research is limited to the Public Financial Reporting Quality of the Sri Lankan public sector. The Sri Lanka Public Sector has three different layers; Central, Provincial and Local Governments. The study will be limited to the Central Government Ministries and Departments.

There is multiple stakeholder base for the PFR including accountants serving for the government. Accountants in the Central Government Ministries and Departments represent Government Accountant Service Members and they are Government Servants specially trained for the financial reporting and considered as subject experts in the Government Ministries and Departments. The research limited its investigation to the views of the accountants serving in the Central Government Ministries and Departments.

\section{LITERATURE REVIEW}

Dissemination of an entity's financial information to the stakeholders is defined as financial reporting (IFAC, 1991). Stakeholders of the public sector organizations and mainly the public can use financial reports to evaluate the performance or results of the decisions taken by the officials. Government policy directives are depending on the public trust (Hetherington, 2006), and the trust is depending on the sufficiency of the financial information available for their concerns (Welch, et al. 2005; Waymire, et al. 2014). According to Safkaur et al. (2019), financial reporting is the key to realizing the accountability of public financial management.

Internal and external users of the financial reporting engaged with the financial reports prepared by the relevant internal parties in an organization. The main objective of financial reporting users' is to enhance the effectiveness of the decisions taken by internal and external users (Tasios and Bekiaris, 2012). Waymire et al. (2014) emphasized the public financial reports is to be included important information for the citizens and government stakeholders. Gimeno (1997), Ouda (2003) argued that it is to included the fundamental and detailed information on the financial position of the public entities to enable the decision-making process. The direct application of financial reporting is to make economic decisions that are based on the information provided by the financial statements and therefore, it helps the entity to have healthy and effective decisions (Mande, 2015). Therefore, Financial Reports in the Public Sector are formulating with the objective in mind of providing full disclosure on a timely basis for all material facts relating to government financial position and operations (Achua, 2009; CICA, 2013; Onyinyechi, et al. 2016).

The quality of financial reporting should be derived by the common phenomenon of quality which is having different meanings depending on the approach. In the context of public financial reporting quality, there are complex considerations including financial information, disclosures, and non-financial information which are useful in decision making (Cheung, et al. 2010). Quality according to Afiah and Rahmatika (2014) is the level of performance that achieves the requirements of inborn individualities. The said achievements of a phenomenon; product, person, process, service, and/or system which is expected to be met expectations or satisfies stated needs, requirements, or specification at the level of fulfilling the totality of features and inherent or assigned characteristics of the phenomenon. Therefore, Information quality is considered the highest priority in the management process, and producing high-quality reporting is again a pivotal function of the management (Renkas, et al. 2016).

There are several definitions of financial reporting quality. As the financial reporting quality broad subject area, several definitions can be investigated based on different user perspectives. The first such definition investigated was Verdi (2006), as "the precision with which financial reports convey information about the firm's operations, in particular its cash flows, to inform equity investors". Tang et al. (2008) argue that the level of fulfilling the true and fair view of the financial statements is expressing the financial performance and the position of the organization as financial reporting quality. The main financial reporting quality objective is to equip the financial reporting users with useful, adequate, and correct data for decision making (IASB, 2008). Zheng (2010) argues that the define financial reporting quality is a difficult task because of the complex environment which inculcates with the vast subject disciplines such as environments, regulations, procedures, and understandings. According to Tasios (2012); 


\section{Influence the Quality of Accounting Information Systems and the Effectiveness of Internal Control on Public Financial Reporting Quality; an Empirical Sturdy}

Palea (2013); Kythreotis (2014); Renkas et al. (2016), quality characteristics can be divided into two basic categories as; fundamental and enhancing. The fundamental information on financial reporting identifies as usefulness and relevancy considering the effect of including non-useful or misleading information for a faithful presentation of information. When the information provided by the financial reports facilitating an alternative option for the decision-makers to take decisions, it is the relevance of the information. Enhancing characteristics are aggravating the effect of fundamental characteristics in the sense of determining the financial reporting quality. Therefore, enhancing characteristics by themselves cannot increase the decision usefulness of the financial reporting and only fundamental characteristics can do it. Namely enhancing characteristics are comparability, timeliness, understandability, and verifiability.

Many scholars such as Dechow and Dichev (2002); Schipper and Vincent (2003); Botosan (2004); Daske and Gebhardt (2006); Beest et al. (2009), admitted that the assessment of quality in financial reporting become complex because of the different arguments over the subject depending on researcher oriented factors. According to Hong (2016), many factors and determinants are influencing financial reporting quality. Financial reporting quality is becoming an interesting study area among accounting standards setters, professionals, as well as practitioners in the field. Hong (2016) in his study, expressed that the difference of the determinants of the financial reporting quality on the grounds while Zheng (2010) emphasized the differences of the quality determinants by different accounting environments and regulations. Finally, based on the considerations, the interpretation of quality of financial reporting remains problematic as described, and different financial reporting environments, regulations, procedures, and understandings are found as leading factors (Catanach, 2003).

According to Hong (2016), many factors and determinants are influencing financial reporting quality. Jones and Rama (2003); Salehi et al. (2010); Ramdany (2015); Susanto (2015); argued that the Accounting Information System (AIS) is one major influential factor that determines the quality of financial reporting in an organization. The AIS is an integrated and interconnected information gathering, processing, and interpreting system which may interconnect physical and non-physical systems, sub-systems, and components effectively and efficiently (Warren et al. 1999; Jones and Rama, 2003; Susanto, 2009). While Susanto (2015), emphasized and acknowledged the that the significant positive influence of AIS over the financial reporting quality, Jones and Rama (2003); Salehi et al. (2010); Ramdany (2015) proves that the AIS as a major influential factor that determines the quality of financial reporting in an organization. The AIS is an important and highly required information processing mechanism in any type of entity (Borthick and Clark, 1990; Curtis, 1995; Rahman et al. 1988; Wilkinson, 1993; Wilkinson et al. 2000). According to Romney and Steinbart (2012), AIS is a process of providing information to the decision-making process by process, store, and presenting raw data in an entity. As pointed out by Saeidi (2014), AIS is the system that generates financial information for the decisionmaking process. Therefore, the AIS should be carefully design and manage. The importance of the AIS had acknowledged by Borthick and Clark (1990); Curtis, (1995); Rahman et al. (1988); Wilkinson, (1993); Wilkinson et al., (2000); Samuel, (2013); in their studies while Wilkinson, (2000) acknowledged the requirement of maintaining the AIS for any kind of organization such as profitoriented, non-profit oriented or public owned. The major expectations of financial reporting are to provide financial information in an effective, efficient, reliable, and secured manner for the decision-making process of the various interested parties. Several scholars argued that the poor design of an AIS in an entity does not assure quality financial information (Abdhali, 2011; Yuzal, 2010; Susanto, 2015). The quality of AIS has been influencing by many factors (Stair \& Reynolds, 2010). According to Susanto (2015), non-integrated systems of AIS does not support quality financial reporting. Laudon and Laudon (2012) argued that the timeliness of the financial reporting while protecting the quality of AIS should also be a priority while Chenhall (2003); Soudani, (2012); Samuel (2013) admitted and tested the scope, timeliness, level of aggregation, and integration as the key dimensions of the quality of AIS.

The Internal Controls are there to carry out the actions and activities by the management and other employees in an entity to generate the financial information which carrying by the financial reporting in a manner that achieving the said objectives (Suwanda, 2015). Petrovits et al., (2011), stated that there are three main objectives of the ICs as; maintaining effectiveness and efficiency, reliability of financial reporting, and encourage adherence to existing laws and regulations. Therefore, it has argued that the effectiveness of the internal control is a major determinant of the quality of financial reporting and which is there to provide reasonable assurance of achieving the entity's goals of justice related to the operation, reporting, and compliance with applicable regulations and weak internal controls may course misleading and wrong financial reporting (Ramdany, 2015). Based on the ground that the relationship of the FRQ and internal controls were studied by many scholars and found that the internal control has been influencing on FRQ in various ways (Dechow et al. 1996; McMullen, 1996; Elbanan, 2008; Afiah and Rahmatika, 2014). Ramdany, (2015), in his studies proved that the FRQ is influenced by the effectiveness of $I C$ of an organization and the main task of IC is to provide reasonable assurance of achieving the entity's goals of justice related to the operation, reporting, and 


\section{Influence the Quality of Accounting Information Systems and the Effectiveness of Internal Control on Public Financial Reporting Quality; an Empirical Sturdy}

compliance with applicable regulations. Through the improvements of effectiveness and efficiency of ICs, it is capable to improve the trustworthiness of the FRQ of an entity (Konrath, 2002). The IC process has the capacity to reflect the accuracy of the financial reporting which is one of the main quality criteria of the financial reporting that leads to achieving financial reporting objectives and the responsibility of establishing such procedures is a function of the management (Chan Li et al. 2015). Kenneman, (2004); Kontrath, (2002); Ricchiute, (2006); Elder, et al. (2009); Boynton, et al. (2011); Jhonstoner, et al. (2012); Aramide and Bashir (2015); emphasized that there are two basic concerns in the IC process as; building reliability in the entity's accountability and compliance mechanism for relevant laws and regulations, for the management of entity's resources to achieve objectives. According to the COSO (2013), a system of IC supporting the financial reporting objectives, the COSO framework deploys five components: Control Environment, Risk Assessment, Control Activities, Information \& Communication, and Monitoring Activities. All five components are pervasive, affecting the other four interrelated components, and are required for an effectively designed internal control system. Arens et al. (2014); Afiah and Rahmatika (2014); Ramdany (2015), in their studies also acknowledges that the effective internal controls include activities of the control environment, risk assessors, information and communication and monitoring activities and these five basic activities are integrated with each other to produce financial reporting.

\section{RESEARCH DESIGN}

\section{a. Research Approach}

The research paradigm has been identified as interpretivism which identifies and determines the real human experience. The phenomenon identified in the research has been tested with the participants' experiences to come to a conclusion. The quantitative research methodology has been applied to measure peoples' attitude, possession, and level of appreciation or acceptance that can be achieved through the quantitative data in quantitative research, and quantitative research instruments. To collect real-time data regarding performance instruments, it has to be employed a questionnaire survey. The quantitative data analysis proceeds from descriptive analysis to multiple regression analysis and multiple regression analysis build a greater refined analysis.

\section{b. Conceptual Framework}

Based on the previous literature, the quality of AIS and the effectiveness of the IC has been identifying as most influential over the financial reporting quality. The research discusses the theoretical and empirical findings in different institutional and situational environments in the public sector environment in Sri Lanka based on the conceptual framework developed as illustrated in Figure 01.

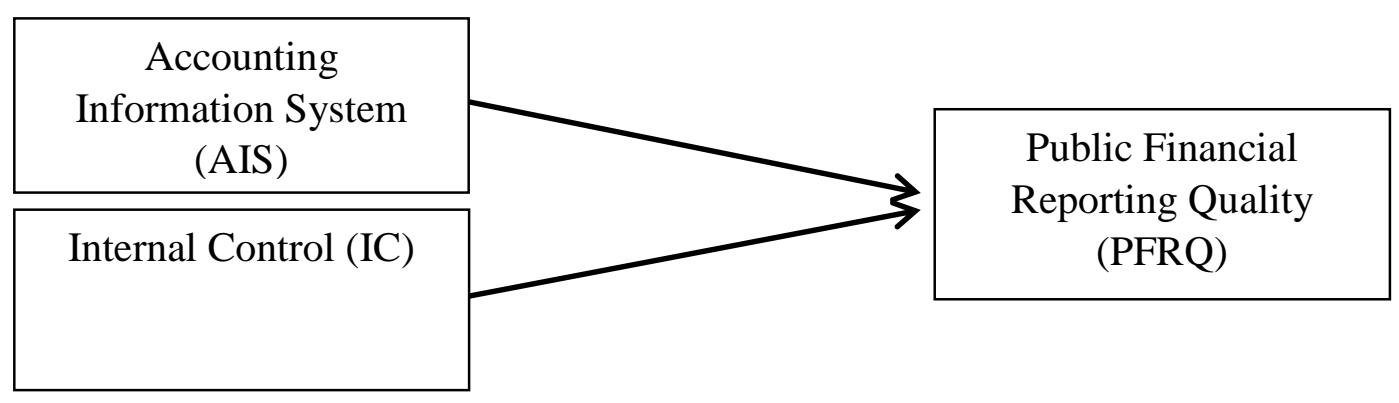

Figure 01: The Conceptual Framework

\section{c. Research Hypothesis}

Considering the conceptual framework developed based on the research objectives and questions, the following hypothesis together with the relevant null hypothesis has been established.

To empirically test the level determining the Public Financial Reporting Quality, the AIS quality in the Sri Lanka Public Sector environment, will be measured by the following null and alternative hypothesis developed in this study;

H01; The quality of AIS is not positively contributing to the PFRQ.

$\mathrm{H} 11$; The quality of AIS is positively contributing to the PFRQ.

As reviewed theoretical description, there is guidance from prior research regarding the determinants of internal control quality. Thus, while it attempted to incorporate this literature in the formulation of hypotheses, the researchers tested the influence of effectiveness of IC by;

$\mathrm{H02}$; The efficiency of IC is not positively contributing to the PFRQ. 


\section{Influence the Quality of Accounting Information Systems and the Effectiveness of Internal Control on Public Financial Reporting Quality; an Empirical Sturdy}

H12; The efficiency of IC is positively contributing to the PFRQ.

\section{d. Population and Sample Selection}

The population for this research is defined as members belonging to the Sri Lanka Accountants' Service who are serving for government ministries and departments in Sri Lanka. The total number of Accountants belonging to the Sri Lanka Accountants' Service according to the Seniority List published by the Accountants Service Section, Ministry of Public Administration in Sri Lanka was 1651. As the study limits to the Central Government Ministries and Central Government Departments, the List was amended by removing Accountants who are engaging with Provincial Councils and Local Governments. There is a total no of 1265 Accountants engaging in Central Government Ministries and Departments. The sample size of the research was selected by using Yaro Yamane's sampling size calculation formula to calculate sample size in this research. Based on the calculation, the sample size has been decided as 304. A private delivery system and postal mails were used to distribute the Questionnaire to the selected sample. Out of 304 Questionnaires distributed, 217 completed questionnaires were returned. The response rate was $71 \%$ in the study which was higher than the accepted minimum rate of $60 \%$ as explained by Black (1999) and Langbein and Felbinger, (2006).

\section{e. Data Collection}

The respondent opinion regarding the relationship of PFRQ and the determinants were recorded by questionnaires. Likert scale type questions having 5-point scale from 'Very High' to 'Very Poor' was used. The scales in the question facilitate participants to mark their level of acceptance or position on a given statement which is designed to measure a phenomenon of research questions (Remenyi, et al. 2002; Saunders, et al. 2009).

\section{f. $\quad$ Validity and Reliability of Data}

Reliability is the degree to which the consistency of the multi-item concept is stable. Similar trends of items are statistically measured and interpreted by the reliability. The Cronbach's alpha statistical calculation is a majorly used measure for internal consistency of responses within each multi-item concept as the most commonly used indicators of internal consistency (Argyrous, 2014). According to Saunders et al. (2016), alpha coefficients can vary between 1 and 0 , whereby alpha scores $\geq 0.7$ indicate a high internal consistency and suggest that the applied scale questions measure the same concept, while other authors such as Johnsen (2012); Hadisantoso et al. (2017) argued that alpha-levels $\geq 0,6$ are acceptable and indicate consistency.

The validity of the data dignified the success of demonstrating the research questions. It is the expected level of representing the phenomenon and the correctness that hopes to fix and tested. There are no validities to be considered such that internal and external effects to data should be addressed by the research (Zikmund, 2000). While involvements causing the study population to identify as an internal threat to validity, external threats generalize involvements causing to other populations.

Research finding in line with the hypothesis developed by the study is defined to measure the internal validity. As Salkind, (2000) explained, internal validity has been restraining by the data composed by the research supported by the hypothesis. The concepts developed by the research are defined and refined by the literature review. Zikmund, (2000) emphasized that the generalizability of the research denominated the external validity of research and it was assured by the research by developing the constructs of the research considering the pretested literature and applying statistically tested sampling techniques for the selecting of samples by population. Curwin \& Slater (2002) in their studies confirm the same by emphasizing the research aligns with the literature or previous scholarly findings and compatibility with the commonly accepted statistical methodologies protected the validity of the data.

\section{g. Data Analysis and Interpretation}

The data analysis employed descriptive analysis, factor analysis, reliability test, and multiple correlation analysis. To test the hypothesis, multiple linear regression was used to describe a linear relationship between independent variables and the dependent variables, and to measure the strength of association (the linear relationship) between PFRQ and constraints such as AIS and IC. Each independent variable is evaluated in terms of its predictive power, over and above that offered by all the other independent variables. Multiple regression is applied in the research as it is the most common and effective technique which are being applied in research in this nature.

The least-square regression model has been used to estimate the effect of independent variables; quality of AIS and the effectiveness of IC, on PFRQ (dependent variable). This equation is represented as follows:

$P F R Q=\beta 0+\beta_{1} A I S+\beta_{2} I C+e$

Where: $F R Q=$ Public Financial Reporting Quality, $\beta 0=$ Intercept, $\beta 1-2=$ Coefficient of the independent variables, AIS $=$ Accounting Information Systems, IC = Internal Controls, e = error term, 
Influence the Quality of Accounting Information Systems and the Effectiveness of Internal Control on Public Financial Reporting Quality; an Empirical Sturdy

\section{DATA ANALYSIS AND INTERPRETATION}

\section{a. Instrument Validation}

The research calculated Cronbach's Alpha values illustrated in Table 2: Cronbach's Alpha Test Results. The Table includes details of the alpha value of the pilot study and details of the alpha value of research scores for the six variables of the study. The alpha coefficient for AIS was 0.818 while the IC variable figured out an alpha value of 0.877 in the reliability testing. The alpha coefficient for both AIS and IC variables expresses a high level of consistent reliability. The dependent PFRQ indicates 0.605 Cronbach's alpha value that is a relatively low value but just above the minimum acceptance level as acknowledged by Pallant, (2016). Considering the fact that the measurements of independent and dependent variables in this research which are consisting of multiple scales have shown an acceptable level of internal consistency as suggested by Pallant, (2016) and Field, (2009).

Table 1: Cronbach's Alpha Test Results

\begin{tabular}{|l|l|}
\hline Variables & Cronbach's Alpha for Main Study \\
\hline Accounting Information System & 0.818 \\
\hline Internal Control & 0.877 \\
\hline Quality of Public Financial Reporting & 0.605 \\
\hline
\end{tabular}

Source: Develop by the Researcher

\section{b. Descriptive Statistics Analysis for the Attributes under each Variable}

The descriptive analysis helps to understand the participants' perception level for each variable and the dimensions of each variable. Descriptive statistics can take the data in mass and be presented in a summarized form and describe it in a meaningful way.

The overall evaluation of the quality of the accounting information system was levelled at the "Poor" category (Mean 2.4, SD 0.4, and Sig. 0.05) as shown in Table 2. Though the Median value of the responses is lower than the Mean value (positively skived), all the Mean, Median, and Mode values-entered to the rated value 2.00-2.50. The efficiency of IC in the government ministries and departments rated by the accountants at a mean value of 2.5 and SD 0.4 (Sig. 0.05) represents below the average rating for the level of satisfaction. In this analysis, it shows that the Median value 2.47 is less than the Mean value 2.53 (Sig. 0.05 ) indicating skewness towards Likert Scale rate 3.0 which represents the "Average" effective level but still the Mode value indicating more towards the "Poor" effectiveness rating. Further, the mean value of the PFRQ was 2.2 at 0.2 SD which rank the quality level as "Poor". The median and mode values were also indicating the same idea expressing the rating close to 2.00 (Table 2). Therefore, it reviled that the overall quality of PFR and the basic determinants (AIS and IC) considered in the research has a low level and the level improvements of determinants identify by this research are vital for the improvements.

Table 2: Descriptive Statistics for the Variables

\begin{tabular}{|l|l|l|l|}
\hline Measurement & Results for the Variable AIS & Results for the Variable IC & Results for the Variable PFRQ \\
\hline Mean & 2.4221 & 2.5359 & 2.2301 \\
\hline Median & 2.3700 & 2.4700 & 2.3300 \\
\hline Mode & 2.30 & 2.47 & 2.00 \\
\hline Std. Deviation & 0.41317 & 0.39827 & 0.42973 \\
\hline Skewness & 0.406 & 0.706 & 0.132 \\
\hline
\end{tabular}

Source: Develop by the Researcher

\section{c. Regression Analysis}

The independent variables were tested for Multicolinearity. The correlation between each independent variable or whether each independent variable is independent of each other is tested by the multicolinearity (Argyrous, 2014). Whether the independent variables are free from multicolinearity problems should be investigated before conducting the multiple regression analysis. According to Pallant (2016), Pearson Correlation $\geq 0.9$ in the multiple regression analysis indicate the problem while Argyrous, (2014) argued that Pearson Correlation $\geq 0.8$ as a cut off level. From the correlation Table 3 below, the Pearson correlation coefficient between AIS and IC is $\mathbf{0 . 4 8 8}$. Therefore, there is no multicolinearity problem in the proposed model indicating according to the Pearson Correlation analysis. 
Influence the Quality of Accounting Information Systems and the Effectiveness of Internal Control on Public Financial Reporting Quality; an Empirical Sturdy

Table 3: Pearson Correlations between independent variables

\begin{tabular}{|l|l|l|}
\hline & AIS & IC \\
\hline AIS & 1.000 & \\
\hline IC & .448 & 1.000 \\
\hline
\end{tabular}

Source: Develop by the Researcher

The Tolerance and VIF (Variance inflation factor) in the Coefficients table also executes collinearity diagnostics. Tolerance is a measurement of one independent variable explained by one another specific independent variable which expected to be maintained less than 0.1 (Tolerance value). Against this calculated VIF (Variance inflation factor) should be maintained more than 10 (Pallant, 2016). The Tolerance and VIF values calculated for the model were indicated in Table 4 and diagnosed with no multicollinearity.

Table 4: Coefficients (Collinearity Statistics)

\begin{tabular}{|l|l|l|}
\hline & Tolerance & VIF \\
\hline AIS & .799 & 1.251 \\
\hline IC & .799 & 1.251 \\
\hline
\end{tabular}

Source: Develop by the Researcher

F-Test in the analysis established the relationship of independent variables $(X)$ with the dependent variable $(Y)$ which demonstrated the model fit $33.964>F$ table $(\alpha=0.05) 2.37$ at significant at $P=0.000$ (Table 5). The results imply that there is a strong relationship between the predictors and the outcomes of the regression variable.

Table 5: ANOVA

\begin{tabular}{|l|l|l|l|l|l|l|}
\hline \multicolumn{2}{|l|}{ Model } & Sum of Squares & Df & Mean Square & F & Sig. \\
\hline \multirow{4}{*}{1} & Regression & 9.579 & 2 & 4.789 & 33.964 & $.000^{\text {b }}$ \\
\cline { 2 - 7 } & Residual & 29.755 & 211 & .141 & & \\
\cline { 2 - 7 } & Total & 39.334 & 213 & & & \\
\hline
\end{tabular}

Source: Develop by the Researcher

The combination of independent variables and dependent variables has been identified by the $R$ values of the analysis (Steel and Torrie, 1960) which has shown in Table 6. In this analysis, independent variables; AIS and IC, has indicated R-value of 0.493 denominating combination between independent variables and dependent variable (Steel and Torrie, 1960). According to the findings, the R2 value is 0.244 which is conveying moderate influence for the total variance of the dependent variable by the independent variables (Cohen et al., 2003). The results express that the coefficient of determination that is the square of the correlation coefficient (R2) in the table is equal to $24.4 \%$ of the variation that occurs in the determinants of public financial reporting quality by all of the independent variables, while the remaining $100 \%-24.4 \%=75.6 \%$ is explained by other variables that are not described in this research.

Table 6: Result of Coefficient Correlation of Multiple Determination Test

\begin{tabular}{|l|l|l|l|}
\hline Model & R & R Square & Adjusted R Square \\
\hline 1 & .493 & .244 & .236 \\
\hline
\end{tabular}

Source: Develop by the Researcher

The statistical significance of the contribution calculated by the analysis is considered in decision making. Table 7, Findings of Multiple Regression (Coefficients table) states that the regression coefficient is positive, $(0.288)$ indicating that the AIS has a positive relationship tends to have quality in Public Financial reporting. The effectiveness of AIS, the higher the quality of Public Financial Reporting, and the relationship is statistically significant (Sig. $=.001$ ). The IC variable also reported a 0.383 regression coefficient indicating statistically significant strong (Sig. $=0.000$ ) relationship.

The multiple regression model applied the calculated beta values can be demonstrated as: PFRQ $=0.707+0.288 \mathrm{AIS}+0.383 \mathrm{IC}+$ $\varepsilon$ which AIS and IC variables were statistically significance. 
Influence the Quality of Accounting Information Systems and the Effectiveness of Internal Control on Public Financial Reporting Quality; an Empirical Sturdy

Table 7: Findings of Multiple Regression

\begin{tabular}{|l|l|l|l|}
\hline & Beta Coefficients & T & Sig. \\
\hline (Constant) & .707 & & \\
\hline AIS & .228 & 3.277 & .001 \\
\hline IC & .383 & 5.294 & .000 \\
\hline
\end{tabular}

Source: Develop by the Researcher

\section{d. Results of Hypothesis Testing}

The results from the multiple regression analysis shows that,

a. The value of $t$ count in the AIS variable is $3.277>t$ table $(\alpha=0.05)$ for 1.6449 and the regression coefficient is indicating 0.228 that impresses statistically significant (Sig.= 0.001 ) unique relationship which denominated the regression coefficient is significant. Therefore, the result of this research shows that the Quality of AIS influences the PFRQ and Null Hypothesis has been rejected.

b. T count in IC variable is $5.294>\mathrm{t}$ table $(\alpha=0.05)$ for 1.6449 and the regression coefficient is positive, (0.383) demonstrating statistically significant (Sig. $=0.000$ ) unique relationship. The results prove that the regression coefficient is significant and the Efficiency of IC influences the PFRQ. The results lead to rejecting the Null Hypothesis.

The Hypothesis testing results which was tested against the AIS have been summarised in Table 8 below.

Table 8: Summery of hypothesis results

\begin{tabular}{|l|l|l|l|}
\hline \multicolumn{2}{|l|}{ Hypothesis } & $\begin{array}{l}\text { Hypotheses' } \\
\text { result }\end{array}$ & Explanation \\
\hline $\mathrm{H}_{01}$ & $\begin{array}{l}\text { The quality of AIS is not positively } \\
\text { contributing to the PFRQ. }\end{array}$ & Rejected & $\begin{array}{l}\text { Quality of AIS significantly influence } \\
\text { to the PFRQ. }\end{array}$ \\
\hline $\mathrm{H}_{02}$ & $\begin{array}{l}\text { The efficiency of IC is not positively } \\
\text { contributing to the PFRQ. }\end{array}$ & $\begin{array}{l}\text { Eejected } \\
\text { influence to the PFRQ }\end{array}$ \\
\hline
\end{tabular}

Source: Develop by the Researcher

\section{RECOMMENDATION AND CONCLUSION}

Financial Information which is providing by the financial reports has been used for the decision-making process in an entity that leads the organization for the future. Providing quality financial reports is the utmost requirement and is the primary objective. Quality of financial reporting in the public sector has become an important subject because of the macroeconomic effect of the decisions taken based on the information scrutinized. There are growing concerns over the determinates of the public financial reporting quality among subject specialists, standard setters, regulators, professionals, and other interested parties and scholars. Four main subject area is being reviled that is influencing finical reporting quality in broad wise; Internal Control and Accounting Information System, by the previous scholar studies.

The research developed the model of determinants of Public Financial Reporting Quality. The model was successfully tested and proved that the Quality of Accounting Information System and the Effectiveness of Internal Controls have been positively contributing to determining the Public Financial Reporting Quality.

The level of Public Financial Reporting Quality in the context of central government ministries and departments in Sri Lanka as measured, was low and should be improved. The financial reporting quality demonstrators as investigated by the research, has found in poor quality level and not even reach to the average level. The Accounting Information System and Internal Controls should be improved and upgraded in the quality improvement process in public sector financial reporting of ministries and departments in Sri Lanka. The regulators and operators of the government financial reporting miracle should pay attention to the improvement of the Accounting Information System and Internal Controls.

The research tested the determinants: Accounting Information Systems and Internal Controls, which are being investigated on several other occasions and applied in the context in Sri Lanka. The research findings reviled that some other factors are also being influenced to determine public financial reporting quality. Therefore, it recommends in this research to investigate the other factors which have been influencing to determine the FRQ. 
Influence the Quality of Accounting Information Systems and the Effectiveness of Internal Control on Public Financial Reporting Quality; an Empirical Sturdy

\section{REFERENCES}

1) Achua, J.K. (2009), Reinventing Governmental Accounting for Accountability Assurance in Nigeria, Nigeria Research Journal of Accountancy, 1(1): 1-16.

2) Adhikari, P. and Mellemvik, F. (2008), Changing Ideology in Nepalese Central Government Accounting Reform. Implementing Reforms in Public Sector Accounting (pp. 141- 150). Coimbra, Portugal: Imprensa da Universidade de Coimbra.

3) Adhikari, P. and Mellemvik, F. (2009), Nepalese Governmental Accounting Development in the 1950s and Early 1960s: An Attempt to Institutionalize Expenditure Accounting, Accounting Historians Journal, 36 (1): 112-133.

4) Afiah, N.N. and Rahmatika, D.N. (2014), Factors Influencing the Quality of Financial Reporting and its Implications on Good Government Governance (Research on Local Government Indonesia), International Journal of Business, Economics and Law, Vol. 5, Issue 1, ISSN 2289-1552.

5) Aramide, S.F. and Bashir, M.M. (2015), The Effectiveness of Internal Control System and Financial Accountability at Local Government Level in Nigeria, International Journal of Research in Business Management, Vol. 3, Issue 8, Aug 2015, 1-6, ISSN (E): 2321-886X; ISSN (P): 2347-4572.

6) Arens, A, A., Elder, R, J., and Beasley, M, S. (2014), Auditing and Assurance Services: An Integrated Approach. Fifteenth Edition. Pearson Education, Essex: England.

7) Arens, (2012), Auditing and Assurance Services: An Integrated Approach, 15th Edition, Pearson Education, New Jersey.

8) Argyrous, G. (2014), Statistics for Research with a Guide to SPSS, SAGE Publication India Ltd., New Delhi, India.

9) Beest, F.V., Braam, G. and Boelens, S., (2009), Quality of Financial Reporting: measuring qualitative characteristics, Nijmegen Centre for Economics (NiCE), Institute for Management Research, Radboud University Nijmegen, P.O. Box 9108, 6500 HK Nijmegen, The Netherlands.

10) Borthick, A.F. and Clark, R.L. (1990), Making accounting information systems work: An empirical investigation of the creative thinking paradigm, Journal of Information Systems, 4(3), 48-62.

11) Botosan, C. (2004), Discussion of a framework for the analysis of risk communication, The International Journal of Accounting, 39(3), 289-295.

12) Boynton W.C., Raymon N.J., Walter G. and Kell, W.G. (2006), Modern Auditing, 8th Edition, Richard D. Irwin Inc., USA.

13) Boynton, W.C., Johnson, R.N. and Kell, W.G. (2011), Modern Auditing, Seventh Edition. John Wiley \& Son, Inc.: New York.

14) Catanach, A.H. and Rhoades, S.C. (2003), A Financial Reporting Failure?, Villanova Law Review 48(4): 1057-1080.

15) Chan Li F.M., McVay S.E. and Skaife H (2015), Does Ineffective Internal Control over Financial Reporting affect a Firm's Operations? Evidence from Firms' Inventory Management, The Accounting Review, American Accounting Association, Vol. 90, No. 2.

16) Chenhall, R.H. (2003), Management control systems design within its organizational context: findings from contingencybased research and directions for the future, Accounting, Organizations and Society, 28, 2-3, 127-168.

17) Cheung, Evans, E and Wright, S. (2010), An historical review of quality in financial reporting in Australia Esther, Pacific Accounting Review, Vol. 22 No. 2, 2010, pp. 147-169, DOI 10.1108/01140581011074520.

18) CICA (2013), Measuring Financial Performance in Public Sector Financial Statements, Conceptual Framework Task Force, Canada Institute of Chartered Accountants (CICA), 277 Wellington Street West, Toronto, Ontario M5V 3H2.

19) COSO, (2013), Internal Control-Integrated Framework, Committee of Sponsoring Organizations of the Treadway Commission, AICPA Publication, New York.

20) CPA, (2013), Parliamentary Series No. 204, $1^{\text {st }}$ Report from the Committee on Public Accounts, The Seventh Parliament of the Democratic Socialist Republic of Sri Lanka.

21) CPA, (2015), Parliamentary Series - No: 376, $1^{\text {st }}$ Session - third report at 2015, The Committee on Public Accounts (CPA), Parliament of the Democratic Socialist Republic of Sri Lanka.

22) Curtis, G. (1995), Business information systems: Analysis, design and practice, Wokingham: Addison-Wesley Publishing Company.

23) Curwin, J. and Slater, R. (2002), Quantitative Methods for Business Decisions, $8^{\text {th }}$ Edition, Cengage Learning EMEA.

24) Daske, H., and Gebhardt, G. (2006), International financial reporting standards and experts' perceptions of disclosure quality, Abacus, 42(3-4), 461-498.

25) Dechow, P., and Dichev, I. (2002), The quality of accruals and earnings: The role of accrual estimation errors, The Accounting Review, 77, 35-59. 
Influence the Quality of Accounting Information Systems and the Effectiveness of Internal Control on Public Financial Reporting Quality; an Empirical Sturdy

26) Dechow, P., Ge, W., and Schrand, C. (2010), Understanding earnings quality: A review of the proxies, their determinants and their consequences. Journal of Accounting and Economics, 50(2-3), 344-401.

27) Dechow, P.M., Sloan, R.G., and Sweeney, A.P. (1996). Causes and consequences of earnings manipulation: An analysis of firms subject to enforcement actions by the SEC, Contemporary Accounting Research, 13(1), 1-36.

28) Elbanan, M. (2008), Quality of Internal Control over Financial Reporting, Corporate Governance and Credit Rating, International Journal of Disclosure and Governance, 127 - 149. doi: 10.1057/jdg.2008.32.

29) Elder, R, J., Beasley, M, S., Arens, A, A. and Joseph, A, A. (2009), Auditing and Assurance Servises: An Integrated Approach. An Indonesian Adaptation, Pearson Education South Asia PTE LTD: Singapore.

30) Field, A. (2005), Discovering Statistics Using SPSS, Sage, London.

31) Gimeno, A. (1997), New public management and its accounting implications: Some references to recent developments in Spanish local authorities, Paper presented at the 6 Biennial CIGAR conference, Milan.

32) Hadisantoso , E. (2017), The Influence of Professionalism and Competence of Auditors towards the Performance of Auditors, Scientific Research Journal, Volume V, Issue I, January 2017 Edition, Page 10-14.

33) Hadisantoso, E., Sudarma, I.M. and Rura Y. (2017), The Influence of Professionalism and Competence of Auditors towards the Performance of Auditors, Scientific Research Journal (SCIRJ), Volume V, Issue I, January 2017.

34) Hetherington, M.J. (2006), Why trust matters: Declining political trust and the demise of American liberalism. Princeton, NJ: Princeton University Press.

35) Hong, N.T.P. (2016), The Determinants of Financial Statement Quality of Companies Listed on Stock Market Evidence in Vietnam, University of Economics, Ho Chi Minh City, Vietnam.

36) IASB, (2008), Exposure Draft on an Improved Conceptual Framework for Financial Reporting: The Objective of Financial Reporting and Qualitative Characteristics of Decision-useful Financial Reporting Information, London.

37) IFAC, (1991), Financial reporting by National Governments, International Federation of Accountants, 529 Fifth Avenue, 6th Floor, New York, NY 10017, www.ifac.org.

38) Jones, F.L. and Rama, D.V. (2003), Accounting Information Systems; A Business Process Approach, Thomson Learning: Canada.

39) Johnson, A. (2012), A short guide to action research (4th ed.), Allyn and Bacon, USA.

40) Kenneman, P. (2004), Check and Balance - Tips to establish effective internal controls, NF Perspective Journal,15 (1) page $1-4$.

41) Kythreotis, A. (2014), Measurement of Financial Reporting Quality Based on IFRS Conceptual Framework's Fundamental Qualitative Characteristics, European Journal of Accounting, Finance \& Business, Volume 2/2014, Issue (3)/ October 2014 ISSN-L 2344-102X.

42) Laudon, K.C. and Laudon, J.P. (2012), Management Information Systems: Managing the Digital Firm, 12th Edition, USA: Prentice Hall.

43) Mande, B., (2015), Perceptions on Government Financial Reporting in Nigeria, Journal of Finance, Accounting and Management, Volume 6(1), pp. 1-22.

44) McMullen, D. (1996), Audit committee performance: An investigation of the consequences associated with audit committees, Auditing, 15(1), 87-103.

45) OECD, (1993), Accounting for What? - The Value of Accruals Accounting to the Public Sector, Paris. The Organisation for Economic Co-operation and Development (OECD), Paris.

46) Onyinyechi, O. C. and Okafor, M. (2016), Efficiency and Accountability of Public Sector Revenue and Expenditure in Nigeria (1970-2014), European Journal of Accounting, Auditing and Finance Research, 4(7), pp. 23-42.

47) Ouda H. A. G., (2003), Public Sector Accounting and Budgeting Reform: The main Issues Involved with special focus on the Arab world, Paper prepared for the Expert Consultative Meeting on Public Administration and Public Accounting Development, With Stress on Electronic Tools Under the Auspices of the United Nations - Economic and Social Commission for Western Asia (ESCWA), 1-3 July 2003, Beirut.

48) Palea, V. (2013), IAS/IFRS and financial reporting quality: Lessons from the European experience, China Journal of Accounting Research, 6 (2013) 247-263.

49) Pallant, J. (2016). SPSS Survival Manual: A Step By Step Guide to Data Analysis Using SPSS Program (6th ed.), London, UK: McGraw-Hill Education. 
Influence the Quality of Accounting Information Systems and the Effectiveness of Internal Control on Public Financial Reporting Quality; an Empirical Sturdy

50) Petrovits, C., Catherine, S. and Aimee S. (2011), The Causes and Consequences of Internal Control Problems in Non-profit Organizations, Accounting Review, Jan 2011, Vol. 86 Issue 1, p325-357.

51) Rahman, M. and Halladay, M. (1988), Accounting information systems: Principles, applications and future directions. New Jersey: Prentice Hall.

52) Ramdany, (2015), Influence The Quality of Accounting Information Systems and The Effectiveness of Internal Control On Financial Reporting Quality, Research Journal of Finance and Accounting, Vol.6, No.6, 2015, ISSN 2222-1697 (Paper) ISSN 2222-2847 (Online).

53) Renkas, J., Goncharenko, O. and Lukianets, O. (2016), Quality of financial reporting: approaches to measuring, International Journal of Accounting and Economics Studies, 4 (1) (2016) 1-5.

54) Remenyi, D., Williams, B., Money, A. and Swartz, E. (2002), Doing Research in Business and Management, Sage Publications Ltd, London, UK.

55) Ricchiute, D, N. (2006), Auditing, Eight Edition, Thomson Learning: Singapore

56) Romney, B., Steinbart, M. and Paul. J. (2012), Accounting Information System, Twelfth Edition. Pearson Education Limited: England.

57) Safkaur, O., Afiah, N.N., Poulus, S. and Dahlan, M. (2019), The Effect of Quality Financial Reporting on Good Governance, International Journal of Economics and Financial Issues, 2019, 9(3), 277-286.

58) Salehi, M., Rostami, V. \& Mogadam, A., (2010), Usefulness of Accounting Information System in Emerging Economy: Empirical Evidence of Iran, International Journal of Economics and Finance, 2(2).

59) Salkind, N.J. (2000), Exploring Research, Prentice Hall, Englewood Cliffs.

60) Samuel, N. (2013), Impact of Accounting Information Systems on Organizational Effectiveness of Automobile Companies in Kenya. University of Nairobi.

61) Saunders, M., Lewis, P. and Thornhill, A. (2009), Research Methods for Business Students, Pearson Education Ltd, $5^{\text {th }}$ ed, London, UK.

62) Saunders, M., Lewis, P. and Thornhill, A. (2016), Research methods for business students ( $7^{\text {th }}$ ed.), Harlow, UK: Pearson Education.

63) Schipper, K., \& Vincent, L. (2003), Earnings quality, Accounting Horizons, 17, 97-110.

64) Sekaran, U. and Bougie, R. (2014), Research Methods for Business; A Skill Building Approch, $7^{\text {th }}$ Edition, Choudhary Press, New Delhi.

65) Soudani, S.N. (2012), The Usefulness of an Accounting Information System for Effective Organizational Performance, International Journal of Economic and Finance, Volume 4, pages 136-145, Publisher Canadian Center of Science and Education: Toronto, Canada.

66) Stair, R.M. and Reynolds, G.W. (2010), Principles of Information Systems. 9th Edition. Boston-USA: Course Technology.

67) Steel, R.G.D. and J.H. Torrie (1960), Principles and Procedures of Statistics, McGrawHill, New York.

68) Susanto, A. (2009), Management Information Systems: Developing, Risk, Structured Approach, First edition, Bandung: Lingga Jaya.

69) Susanto. A. (2013), Accounting Information Systems, Control Structure, Risk and Development, Lingga Jaya: Bandung.

70) Susanto, A. (2015), What Factors Influence the Quality of Accounting Information?, I J A B E R, Vol. 13, No. 6 (2015): 39954014.

71) Tasios, S. (2012), Auditor's perceptions of financial reporting quality: the case of Greece, International Journal of Accounting and Financial Reporting, Vol. 2, No. 1 2012, ISSN 2162-3082

72) Tasios S. and Bekiaris, M. (2012), Auditor's perceptions of financial reporting quality: the case of Greece, International Journal of Accounting and Financial Reporting, ISSN 2162-3082 2012, Vol. 2, No. 1.

73) Tang Q., Chen H. and Zhijun L, (2008), Financial reporting quality and investor protection: a global investigation, Working Paper.

74) TISL, (2014), Sri Lanka Governance Report 2012/13, Transparency International, Sri Lanka,

75) USAID (2015), Sri Lanka Public Financial Management Assessment Report, Asia and the Middle East Economic Growth Best Practices (AMEG) Project, United States Agency for International Development (USAD)

76) Verdi, R.S. (2006), Financial Reporting Quality and Investment Efficiency, Copyright UMI, Dissertation Publishing. Ann Arbor, USA. 
Influence the Quality of Accounting Information Systems and the Effectiveness of Internal Control on Public Financial Reporting Quality; an Empirical Sturdy

77) Warren, C.S., Reeve, J.M. and Fess, P.E. (1999), Financial and Managerial Accounting, 6th Edition, International Thomson Publishing, USA.

78) Waymire T.R., Sohl, S.N. and Howard B. (2014), Public Administrators' Understanding of External Financial Reporting: It Begins With Curriculum, Journal of Public Affairs Education, JPAE 21 (2), 281-294.

79) Welch, E.W., Hinnant, C.C., and Moon, M.J. (2005), Linking citizen satisfaction with e-government and trust in government, Journal of Public Administration Research and Theory, 15(3), 371-392.

80) Wilkinson, J.W. (1989), Accounting Information System: essential concepts and applications, John Wiley \& Sons Inc.

81) Wilkinson, J. W. (1993), Accounting information systems: Essential concepts and applications, Second Edition, New York: John Wiley \& Sons Inc.

82) Wilkinson, J. W., Cerullo, M.J., Raval, V. and Won-On-Wing, B., (1999), Accounting Information Systems: Essential Concepts and Applications, Fourth Edition, John Wiley \& Son, Inc., USA.

83) Zheng, X. (2010), A Comparative Study of Financial Reporting Quality, Business and Management 2010, 6th International Scientific Conference, May 13-14, 2010, Vilnius, Lithuania, ISSN 2029-4441 print / ISSN 2029-428X CD, doi:10.3846/bm.2010.039.

84) Zikmund, W.G. (2000), Business Research Methods, Harcourt, Orlando. 